\title{
Correction to: Community mobilisation approaches to preventing and reducing adolescent multiple risk behaviour: a realist review protocol
}

Laura Tinner*, Deborah Caldwell and Rona Campbell

Correction to: Syst Rev 10:147, (2021)

https://doi.org/10.1186/s13643-021-01696-4.

In the original publication of this article [1], the authors' names, Laura Tinner, Deborah Caldwell and Rona Campbell, were incorrectly captured. The given names and family names were interchanged. The original article has been corrected.

Published online: 07 June 2021

\section{Reference}

1. Tinner L, Caldwell D, Campbell R. Community mobilisation approaches to preventing and reducing adolescent multiple risk behaviour: a realist review protocol. Syst Rev. 2021;10:147 https://doi.org/10.1186/s13643-021-01696-4.

The original article can be found online at https://doi.org/10.1186/s13643021-01696-4.

* Correspondence: laura.tinner@bristol.ac.uk

Population Health Sciences, Bristol Medical School, Canynge Hall, University

of Bristol, Bristol BS8 2PL, UK

(c) The Author(s). 2021 Open Access This article is licensed under a Creative Commons Attribution 4.0 International License, which permits use, sharing, adaptation, distribution and reproduction in any medium or format, as long as you give appropriate credit to the original author(s) and the source, provide a link to the Creative Commons licence, and indicate if changes were made. The images or other third party material in this article are included in the article's Creative Commons licence, unless indicated otherwise in a credit line to the material. If material is not included in the article's Creative Commons licence and your intended use is not permitted by statutory regulation or exceeds the permitted use, you will need to obtain permission directly from the copyright holder. To view a copy of this licence, visit http://creativecommons.org/licenses/by/4.0/ The Creative Commons Public Domain Dedication waiver (http://creativecommons.org/publicdomain/zero/1.0/) applies to the data made available in this article, unless otherwise stated in a credit line to the data. 